\title{
Pregnancy diagnosis in cattle using pregnancy associated glycoprotein concentration in circulation at day 24 of gestation
}

\author{
S.T. Reese ${ }^{\text {a }}$, M.H.C. Pereira ${ }^{\text {b }}$, J.L. Edwards ${ }^{\text {a }}$, J.L.M. Vasconcelos ${ }^{\text {b }}$, K.G. Pohler ${ }^{\text {a, * }}$ \\ ${ }^{a}$ Department of Animal Science, University of Tennessee, 2506 River Drive, Knoxville, TN, United States \\ ${ }^{\mathrm{b}}$ Department of Animal Production, São Paulo State University, Botucatu, SP, Brazil
}

\section{A R T I C L E I N F O}

\section{Article history:}

Received 23 August 2017

Received in revised form

5 October 2017

Accepted 9 October 2017

Available online 12 October 2017

\section{Keywords:}

Pregnancy

Cattle

Pregnancy associated glycoproteins

Pregnancy loss

\begin{abstract}
A B S T R A C T
Cattle producers are limited to day 28-30 of gestation as the earliest time point for accurate pregnancy diagnosis due to the effectiveness of ultrasound and chemical based methods, including commercially available pregnancy associated glycoproteins (PAG) tests. The objective of the current studies were to determine if early gestation circulating PAG concentrations at day 24 could be used to diagnose pregnancy in dairy cattle undergoing embryo transfer. In vitro produced embryos were transferred into Holstein $x$ Gir cows and heifers on day 7 following ovulation. Study 1 utilized only cows $(n=101)$ determined to be pregnant on day 24 of gestation by progesterone concentration, as well as CL and PAG presence. In study 2 , animals were not predetermined to be pregnant and both heifers $(\mathrm{n}=111)$ and cows $(n=242)$ were used. In both studies, blood was collected at day 24 for PAG analysis as well as day 31. Final pregnancy confirmation occurred on day 60 via transrectal ultrasonography. Serum PAG concentrations were quantified using an in house PAG ELISA. Following timed embryo transfer (TET) in study 1 , of the 101 cows diagnosed as pregnant on day 24,80 cows were identified as still pregnant on day 31 of gestation (77\%). Study 2 had a pregnancy rate at day 31 of $33.7 \%$ of total embryos transferred. Mean circulating PAG concentration at day 24 differed $(\mathrm{P}<0.001)$ between animals diagnosed pregnant and non-pregnant at day 31 in both studies (study $1,2.964 \pm 0.262 \mathrm{ng} / \mathrm{mL}$ vs $0.946 \pm 0.168 \mathrm{ng} / \mathrm{mL}$ and study $2,1.962 \pm 0.261 \mathrm{ng} / \mathrm{mL}$ vs $0.731 \pm 0.109 \mathrm{ng} / \mathrm{mL}$ ). Concentration of PAG between pregnant and nonpregnant cows in study 1 and 2 was significant, however, pregnant heifers in study 2 $(1.562 \pm 0.266 \mathrm{ng} / \mathrm{mL})$ had concentration of PAGs that only had a tendency to differ compared to nonpregnant heifers (non-pregnant, $0.799 \pm 0.290 \mathrm{ng} / \mathrm{mL} ; \mathrm{P}=0.0669$ ). Only animals that were pregnant at day 31 were analyzed in late embryo mortality analysis (heifers, $n=54$; cows, $n=159$ ), defined as pregnancy loss between day 31 and 60. Between day 31 and 60, 39 (12 in study 1 and 28 in study 2) animals experienced late embryo mortality. Circulating concentrations of PAG were not significantly different $(P>0.05)$, in either study, at day 24 of gestation in animals that maintained pregnancy until day 60 compared to animals that lost pregnancy between day 31 and 60 (late embryo mortality, LEM). In summary, early gestation circulating PAG concentration may have application in diagnosing pregnancy at day 24 of gestation and more work is needed to determine the potential of early gestation PAGs in predicting embryo loss in dairy.
\end{abstract}

(C) 2017 Elsevier Inc. All rights reserved.

\section{Introduction}

Identifying cost effective and accurate methods to determine cow pregnancy status is a priority for decreasing interbreeding intervals and increasing reproductive efficiency of dairy cattle.

\footnotetext{
* Corresponding author. Department of Animal Science, A112 Johnson Animal Research and Teaching Unit, 1750 Alcoa Hwy, Knoxville, TN 37920, United States. E-mail address: kpohler@utk.edu (K.G. Pohler).
}

Pregnancy detection by palpation, ultrasound or chemical based tests is utilized by greater than $90 \%$ of dairy producers [1]. Ability to do so accurately is currently limited to around day 28 of gestation. This coincides with the earliest time point for detection of a heartbeat via ultrasound and is the earliest point to date for effective use of a commercially available Pregnancy Associated Glycoprotein (PAG) pregnancy diagnosis assay. Palpation per rectum is further restricted, even when performed by an experienced technician, between days 35 and 40 for accurate diagnosis 
$[2,3]$. Chemical based pregnancy tests are increasing in popularity. Three commercial platforms offer pregnancy diagnosis assays by detection of PAGs in blood and milk samples beginning at day 28-30 of gestation.

Pregnancy associated glycoproteins are placental products secreted into maternal circulation detectable around day 22 of gestation. A study by Pohler et al. [4] identified day 24 as the first significant increase in detectable PAG concentration in postpartum suckled beef cows undergoing timed artificial insemination (TAI) [4]. Additional research indicated that PAG concentrations between days $28-31$ of gestation have the potential to be strong predictors of late embryonic success in both beef and dairy cattle [4-7]. Specific to lactating dairy cows, increased circulating concentrations of PAGs at day 31 had a higher likelihood of pregnancy success while cows with decreased concentrations of PAGs had a greater likelihood of embryonic mortality between days 31-60 [8]. Pregnancy loss between days 30-60, hereafter termed late embryonic mortality (LEM), poses a significant economic challenge and increases the interbreeding interval of animals that experience it compared to pregnancy losses before day 30 of gestation [9].

Late embryonic mortality in lactating dairy cattle is $~ 12 \%$ [10]. Variation however, does exist between farms, breeding method, parity and seasonality with reported ranges varying from 10 to over $25 \%$ [11-13]. The highest rates of LEM often occur in pregnancies from in vitro produced embryos with losses averaging 20\% [14,15]. In 2016, Pohler et al. [8] showed that day 31 circulating PAG concentrations were predictive of pregnancy success in cows after transfer of in vitro produced embryos. Pregnancy loss between day $24-31$ of gestation was $20.8 \%$ in the same study. In addition, PAG concentrations at day 24 were significantly different between cows diagnosed pregnant or non-pregnant using ultrasound. What Pohler et al. [8] did not do however, was assess the actual accuracy of day 24 circulating PAG concentrations as a tool to diagnosis pregnancy or as a predictor of pregnancy success until day 60 of gestation.

Combining the potential of PAGs as an early pregnancy diagnosis tool (pregnant or not) and their use to predict LEM between days $30-60$, the objective of this study was to determine if (1) circulating day 24 PAG concentrations could be useful to diagnosis the pregnancy status of lactating dairy cattle undergoing embryo transfer using in vitro derived embryos, and (2) if day 24 PAG concentrations are predictive of pregnancy loss/maintenance until day 60 of gestation.

\section{Materials and methods}

\subsection{Animals}

All protocols followed the guidelines recommended in the Guide for the Care and Use of Agricultural Animals in Agricultural Research and Teaching. Cows and heifers were housed at a commercial dairy farm in Minas Gerais, Brazil.

\subsection{Study one}

To assess the actual accuracy of day 24 circulating PAG concentrations as a tool to diagnosis pregnancy or as a predictor of pregnancy success to day 60 of gestation, a retrospective analysis of data originating from the third experiment described in Pohler et al. [8] was performed. Relevant for that study, a total of 142 embryos were transferred on day 7 following a synchronized estrus; a total of 101 lactating Gir $\times$ Holstein cows averaging $109 \pm 10.6$ days in milk had (1) detectable circulating PAG on day 24 (concentration $>0.28 \mathrm{ng} / \mathrm{mL}$; baseline of assay), (2) a well vascularized corpus luteum (CL) detected by Doppler ultrasound present ipsilateral to where the embryo was deposited [16], and (3) circulating progesterone concentration greater than $1 \mathrm{ng} / \mathrm{mL}$ on day 24 . Transrectal ultrasound was performed to confirm presence of an embryo/fetal heartbeat on day 31 and 59 of gestation.

Serum samples originating from Pohler et al. [8] on day 24 following embryo transfer were assayed for circulating concentrations of PAG using an in house sandwich ELISA protocol established by Green et al., (2005) and modified using a polyclonal antibody raised against early secreted PAGs (Ab 45) that is identical to the assay used in Pohler et al., (2013) with a sensitivity of $0.28 \mathrm{ng} / \mathrm{mL}$ PAG concentration.

\subsection{Study two}

Based on outcomes from the retrospective analysis of Pohler et al., in study 1 we then conducted a second study to determine if circulating day 24 PAG concentrations were accurate in diagnosing pregnancy status of lactating dairy cattle undergoing embryo transfer using in vitro derived embryos, and determine if day 24 PAG concentrations are predictive of pregnancy loss/maintenance until day 60 of gestation. This study used Gir $\times$ Holstein cows $(\mathrm{n}=242)$ and pubertal heifers $(\mathrm{n}=111)$ ranging from $1 / 2$ to $7 / 8$ Holstein. All animals were estrus synchronized with the following protocol; an intravaginal progesterone (P4) insert containing $1.9 \mathrm{~g}$ of P4 (Zoetis, São Paulo, Brazil) and $2.0 \mathrm{mg}$ (im) of estradiol benzoate $(2.0 \mathrm{~mL}$ of Estrogin, Farmavet, São Paulo, SP, Brazil) on day $-11,25 \mathrm{mg}$ (im) of dinoprost (prostaglandin $\mathrm{F}_{2 \alpha} ; 5.0 \mathrm{~mL}$ of Lutalyse, Zoetis) on day -4 , intravaginal-P4-insert withdrawal and $1.0 \mathrm{mg}$ (im) of estradiol cypionate ( $0.5 \mathrm{~mL}$ of ECP, Zoetis) on day -2 and ovulation was assumed on day 0 . Fresh high-quality morulae or early blastocyst stage embryos produced in vitro from Holstein donors and high fertility, frozen thawed Holstein semen were transferred on day 7 via timed embryo transfer (TET).

Blood samples were collected at day 17 to provide a baseline PAG concentration, day 24 for early pregnancy diagnosis and day 31 for standard pregnancy diagnosis and processed according to Pohler et al. [8]. Transrectal ultrasound was used to determine pregnancy status on day 31 and day 60 of gestation via fetal heartbeat. Pregnancy loss was defined as the absence of an embryo/ fetus or an embryonic/fetal heartbeat.

Concentrations of PAG were quantified using a different, polyclonal antibody raised against early secreted PAGs (Ab 63) with a similar assay set up as previously described $[5,18]$. The Ab 63 rabbit was immunized with a PAG prep that was isolated by using the A6 monoclonal antibody. This PAG prep was purified by using bovine cotyledons from mid-gestation ( day 150). The cotyledons were homogenized and the extract was placed in 50,000 molecular weight cut-off (MWCO) dialysis tubing (Spectrum Laboratories) and dialyzed against $\sim 700 \mathrm{vol}$ of $20 \mathrm{mM}$ Tris, $150 \mathrm{mM} \mathrm{NaCl}, 1.0 \mathrm{mM}$ EDTA, 0.2 mM PMSF, 0.02\% (w/v) $\mathrm{NaN}_{3}, 0.1 \mathrm{mM} 2$-mercaptoethanol, $\mathrm{pH}$ 7.0. The cotyledon extract was centrifuged to remove insoluble debris and the proteins in the supernatant were precipitated by sequential addition of $\left(\mathrm{NH}_{4}\right)_{2} \mathrm{SO}_{4}$ to $40 \%$ saturation. The solution was cleared by centrifugation at $8000 \mathrm{~g}$ for $10 \mathrm{~min}$. Saturated ammonium sulfate was slowly added to the cleared solution until $80 \%$ saturation was achieved. The precipitated proteins were collected by centrifugation at $8000 \mathrm{~g}$ for $10 \mathrm{~min}$. Pelleted material was resuspended and dialyzed against $\sim 1000$ vol to achieve a final buffer composition of $0.1 \mathrm{M}$ Tris, $0.15 \mathrm{M} \mathrm{NaCL}$, pH 7.6. This $40-80 \%$ fraction was applied to a column containing $50 \mathrm{~mL}$ of Agarose Avidin D (Vector Laboratories) matrix that had been bound to $50 \mathrm{mg}$ of biotinylated A6 anti-PAG monoclonal antibody. The affinity matrix had been previously equilibrated in $0.1 \mathrm{M}$ Tris, $0.15 \mathrm{M}$ $\mathrm{NaCL}, \mathrm{pH}$ 7.6. After applying the extract to the column, it was washed with 10 column volumes of the same buffer, followed by 10 
column volumes of $20 \mathrm{mM}$ Tris, $1.0 \mathrm{M} \mathrm{NaCl}, 0.1 \%$ Tween-20, $\mathrm{pH} 8.0$ and another 25-30 column volumes of $0.1 \mathrm{M}$ Tris, $0.15 \mathrm{M} \mathrm{NaCl}, \mathrm{pH}$ 7.6. Proteins remaining bound to the column were eluted by using a glycine buffer ( $0.1 \mathrm{M}$ glycine, $\mathrm{pH} 2.9$ ). The fractions were immediately neutralized with $1.0 \mathrm{M}$ Tris, $\mathrm{pH}$ 9.5. Eluted fractions were collected and assessed for the presence of PAGs by dot blot. Those fractions that contained PAG immunoreactivity were pooled and concentrated by dialysis against polyethylene glycol (PEG 15,000-20,000 MW). The PAGs present in the purified isolate $(30 \mu \mathrm{g})$ were submitted to the Charles W. Gehrke Proteomics Center at the University of Missouri to be identified by Nano-LC Nanospray QTOF MS/MS. The main PAGs present in the prep were PAG 6 and 4. This isolate was used to immunize and boost a rabbit by following methods described previously $[18,19]$.

Plates were laid out the same as described for study 1 with all samples run in duplicate, a serial dilution protein standard, a nonpregnant pooled cow serum and a third trimester pregnancy pooled cow serum control.

\subsection{Statistical analysis}

Statistical analysis was conducted using a one-way ANOVA in "PROC GLM" (SAS Institute Inc., Cary, NC) to test for differences in circulating PAG concentration. Differences were considered significant if the $\mathrm{P}<0.05$ while a tendency was described if $0.05<\mathrm{P}<0.10$. MedCalc software was used to create Receiver Operating Characteristic [20] curves where pregnancy was designated as the true positive. Predictive value analysis based on the ROC curve was used to determine a PAG concentration where a cow could be diagnosed as pregnant with $90 \%$ accuracy.

\section{Results}

\subsection{Study 1}

On day 7, 142 embryos were transferred into lactating dairy cows, 101 met the criteria to be considered pregnant at day 24 of gestation. Of 101 cows which were diagnosed pregnant on day 24 , 80 were pregnant on day 31 via embryonic heartbeat. Pregnancy rate for study 1 was $56.34 \%$ (80/142) at day 31 of gestation. Embryonic loss between days $7-24$ was $29 \%(n=41)$ and from days $7-31$ was $44 \%(n=62)$. Mean circulating PAG concentration at day 24 of cows diagnosed as pregnant on day 31 of gestation was $2.9635 \pm 0.262 \mathrm{ng} / \mathrm{mL}$ (mean $\pm \mathrm{SEM}$, range $0.445-14.995 \mathrm{ng} / \mathrm{mL}$ ). Cows identified as non-pregnant (no embryonic heartbeat) at day 31 had a significantly lower $(\mathrm{P}<0.001)$ day 24 circulating PAG concentration $(0.946 \pm 0.168 \mathrm{ng} / \mathrm{mL}$, range $0.365-3.750 \mathrm{ng} / \mathrm{mL})$ compared to pregnant animals (Fig. 1). A ROC curve was used to test the potential effectiveness of day 24 circulating PAG concentration and had an area under the curve of $88.4 \%$ (Fig. 2). In this set of samples using polyclonal antibody Ab45, a positive (pregnant) predictive value was identified at $1.635 \mathrm{ng} / \mathrm{mL}$ for $90 \%$ confidence and $1.865 \mathrm{ng} / \mathrm{mL}$ for $95 \%$ confidence. While all cows were considered pregnant at day 24, 58 cows would have been recognized as pregnant using the positive predictive value of $1.635 \mathrm{ng} / \mathrm{mL}$ and 51 cows using $1.865 \mathrm{ng} / \mathrm{mL}$. Of animals classified as pregnant using the predictive cutoff value, $94 \%$ were pregnant via ultrasound at day 31. There were too few negative (non-pregnant) outcomes to establish a predictive value to identify non pregnant animals. Pregnancy loss between day 31 and 60 occurred in 12 cows, resulting in a LEM rate of $11.8 \%$. Circulating PAG concentration at day 24 was not different for cows that maintained pregnancy $(\mathrm{n}=68 ; 2.829 \pm 0.241 \mathrm{ng} / \mathrm{mL})$ and for cows $(\mathrm{n}=12 ; 3.715 \pm 1.098 \mathrm{ng} / \mathrm{mL})$ that experienced embryo mortality using this specific antibody combination.

\subsection{Study 2}

Study 2 examined the potential use of a different antibody, Ab63, to diagnose pregnancy with day 24 circulating PAG concentrations. On day 7, 353 embryos were transferred and at 31 days of gestation 131 animals were diagnosed pregnant, presenting a pregnancy rate of $33.7 \%$. Pregnancy rates were lower in cows (33.1\%) than in heifers (48.6\%) (Fig. 3). Animals possibly experienced pregnancy loss between day 24 and 31 if day 24 samples had a PAG concentration increase of at least $1 \mathrm{ng} / \mathrm{mL}$ compared to the day 17 sample but were not pregnant at day 31. A total of 8 heifers and 22 cows were not pregnant at day 31 after a having PAG increase from day 17-24 (18.6\% loss from day 24 to day 31 ); therefore, identified as candidates of likely embryo loss between day 24 and 31. Animals diagnosed at day 31 as pregnant had a higher day 24 circulating PAG concentration $(1.962 \pm 0.261 \mathrm{ng} / \mathrm{mL})$ than animals diagnosed as non-pregnant $(0.731 \pm 0.109 \mathrm{ng} / \mathrm{mL} ; \mathrm{P}<0.0001)$. Concentrations of PAG at day 24 in pregnant cows was $2.232 \pm 0.369 \mathrm{ng} / \mathrm{mL}$; while non-pregnant cows had a decreased circulating concentration of $0.707 \pm 0.114 \mathrm{ng} / \mathrm{mL}(\mathrm{P}<0.0001)$ (Fig. 4). Pregnant heifers had a tendency for higher circulating PAG concentration $(1.562 \pm 0.266 \mathrm{ng} / \mathrm{mL}, \mathrm{P}=0.0669)$ than nonpregnant heifers $(0.799 \pm 0.290 \mathrm{ng} / \mathrm{mL})$; however, it was not significantly different than pregnant cows $(P=0.1309)$. There was no difference at day 24 or 31 between cows with breed variation $(P>0.05)$ based on the percentage of Bos indicus influence. At day 31 , pregnant animals had a mean circulating PAG concentration of $8.605 \pm 0.439 \mathrm{ng} / \mathrm{mL}$ whereas non-pregnant animals have a concentration of $1.243 \pm 0.248 \mathrm{ng} / \mathrm{mL}(\mathrm{P}<0.0001)$.

For pregnancy diagnosis at day 24 , a ROC curve was used to test the potential effectiveness of day 24 PAG concentration and had an area under the curve of $73.4 \%$ (Fig. 5). Based on predictive value analysis, there was not a clear cutoff value for identification of nonpregnant animals similar to study 1 due to significant overlap between pregnant and non-pregnant PAG concentrations. Positive predictive value analysis concluded a concentration of $2.50 \mathrm{ng} / \mathrm{mL}$ resulted in a $90 \%$ confidence that the animal was pregnant, $95 \%$ confidence requires a concentration of $3.71 \mathrm{ng} / \mathrm{mL}$.

Using $2.50 \mathrm{ng} / \mathrm{mL}, 56$ animals (cows, $\mathrm{n}=42$; heifers, $\mathrm{n}=14$ ) were identified with 33 (cows, $n=24$; heifers, $n=9$ ) of these animals pregnant on day 31 via embryonic heartbeat. In addition, 90.1\% of animals with a circulating PAG concentration of at least $2.5 \mathrm{ng} / \mathrm{mL}$ had an increased PAG concentration of at least $0.75 \mathrm{ng} /$ $\mathrm{mL}$ compared to the day 17 baseline sample. However, the day 17 baseline was not effective for increasing the accuracy of pregnancy diagnosis. Increased circulating PAG concentration of at least $0.75 \mathrm{ng} / \mathrm{mL}$ at day 24 compared to the day 17 baseline sample accurately diagnosed pregnancy in only 51\% (69/134) of animals that were pregnant at day 31. Of these 69 animals, 30 were heifers that had a $0 \mathrm{ng} / \mathrm{mL}$ baseline sample. Late embryonic mortality (LEM) after day 31, but before the final pregnancy diagnosis at day 60 occurred in 28 animals (7.93\%). Heifers experienced LEM at a rate of $8.11 \%$ (9/111 all heifers; $9 / 54,17 \%$ of pregnant heifers) while $7.85 \%$ of all cows (19/242 all cows; $19 / 80,24 \%$ of pregnant cows) suffered late embryo loss. Only animals diagnosed as pregnant at day 31 were included in the LEM analysis (heifers, $\mathrm{n}=54$; cows, $\mathrm{n}=80$ ). There was no difference in day 24 PAG concentration $(\mathrm{P}=0.2284)$ between animals that maintained $(\mathrm{n}=106$, $2.043 \pm 0.167 \mathrm{ng} / \mathrm{mL}$ ) or lost pregnancy between day 31-60 of gestation ( $\mathrm{n}=28,1.327 \pm 0.251 \mathrm{ng} / \mathrm{mL}$; Fig. 6). Day 24 concentrations of PAG in cows that lost pregnancy between day 31 and 60 $(\mathrm{n}=19,1.680 \pm 0.299 \mathrm{ng} / \mathrm{mL})$ had a decrease but was not different $(\mathrm{P}=0.4687)$ from cows that maintained pregnancy $(\mathrm{n}=61$, $2.264 \pm 0.237 \mathrm{ng} / \mathrm{mL})$. Although not significant $(\mathrm{P}=0.3430)$, heifers which maintained pregnancy also had an increased mean day 24 


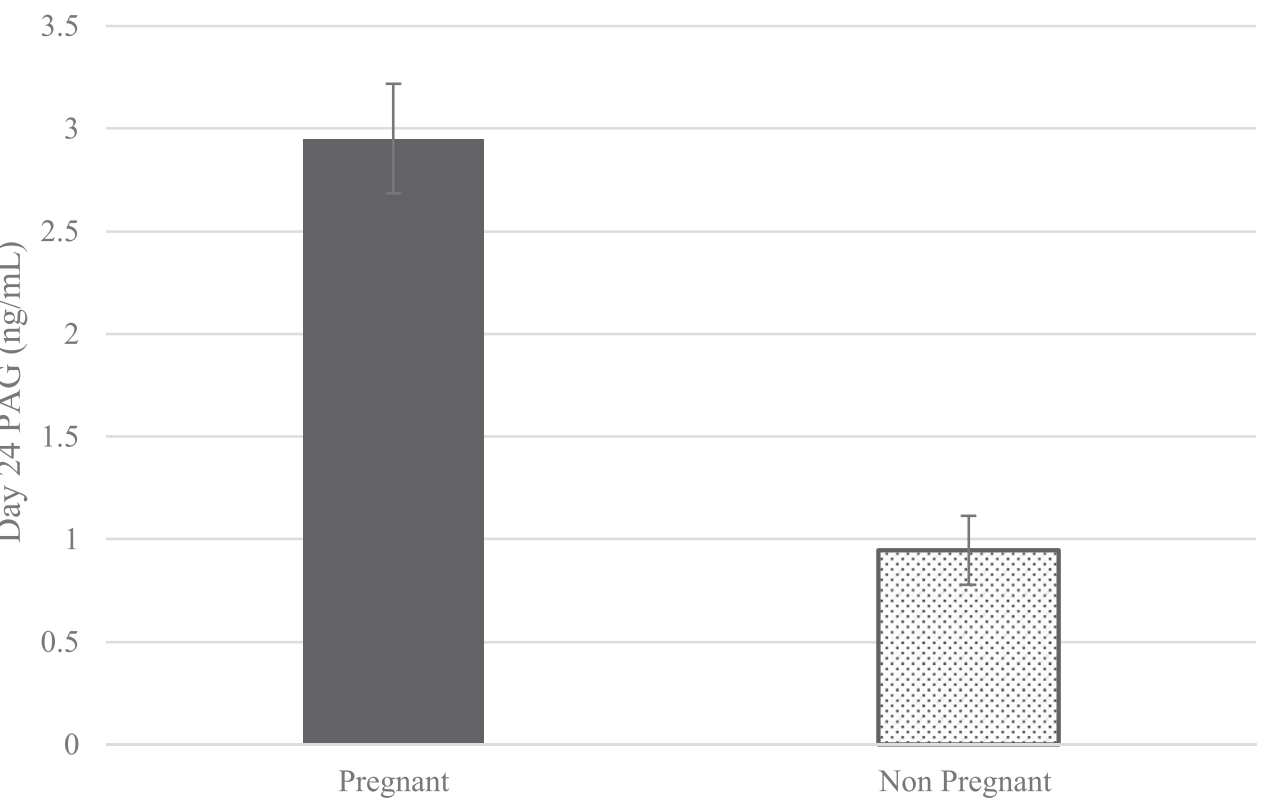

Fig. 1. Study 1 day 24 PAG concentration.

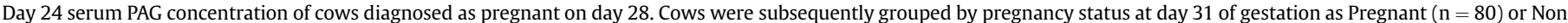

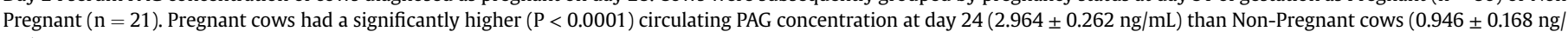
$\mathrm{mL})$.

PAG concentration $(\mathrm{n}=45,1.728 \pm 0.206 \mathrm{ng} / \mathrm{mL})$ over heifers which lost a pregnancy $(\mathrm{n}=9,0.738 \pm 0.246 \mathrm{ng} / \mathrm{mL})$.

\section{Discussion}

Pregnancy rates in dairy cattle are highly variable and dependent on genetics, production and environmental factors [10,21]. A

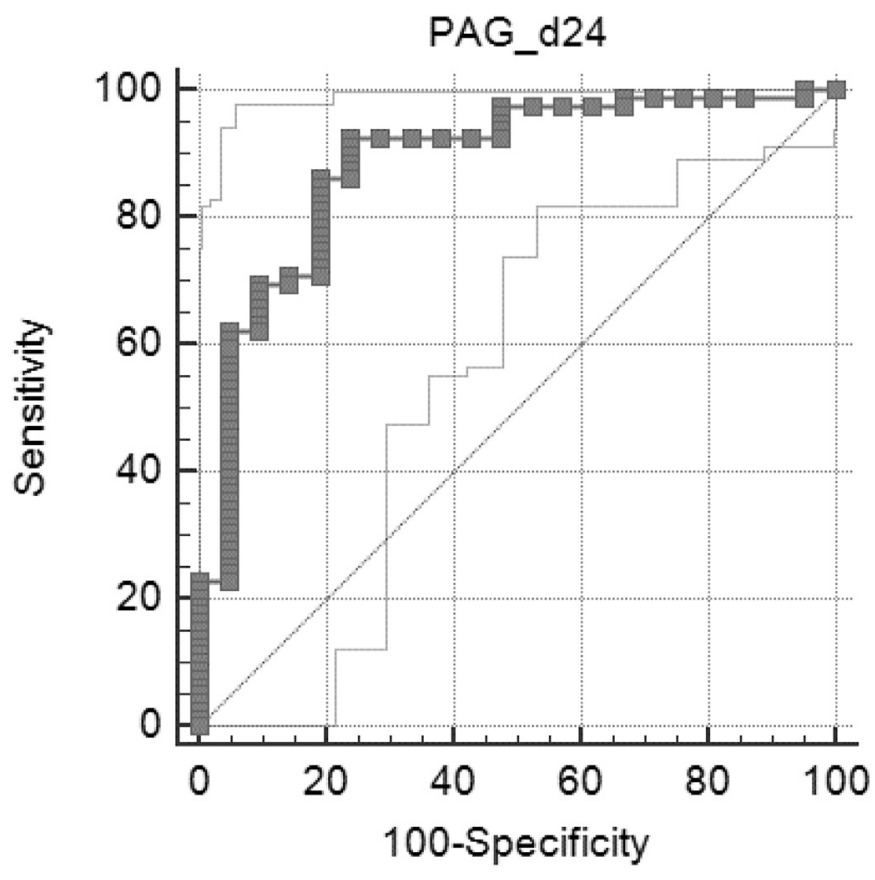

Fig. 2. Study 1 day 24 ROC curve using antibody 45 to diagnose pregnancy. Receiver operating characteristic (ROC) curve was used for predictive value analysis The area under the curve was $88.4 \%$ and a positive predictive value at $95 \%$ confidence to diagnose pregnancy at day 24 of $1.865 \mathrm{ng} / \mathrm{mL}$. review of pastured dairy cattle by Diskin et al. [22] indicated that average loss by day 32 is $53 \%$, however early embryonic loss in TET pregnancies is often higher and in the current study 2 was $66 \%$. A Brazilian study of TET in dairy cattle reported loss of $58 \%$ by day 32 [23]. A large study looking at TET using embryos produced with sex sorted semen reported loss of $62 \%$ [24]. Influence of Bos indicus breeds may have reduced the impact of heat stress associated with a tropical climate which severely undermines reproduction efficiency in lactating Holsteins $[25,26]$; however, a study by Pontes et al. [27] indicated pregnancy rates from in vitro produced embryos were not different between purebred Holstein, purebred Gir or Holstein-Gir crossbred dairy cattle after timed embryo transfer. With significant pregnancy loss occurring by day 31 of gestation, early pregnancy diagnosis and identification of successful pregnancies would reduce the interbreeding and calving interval in dairy herds by allowing resynchronization and rebreeding measures to be taken earlier.

Our results confirmed that day 24 circulating PAG concentrations are elevated in pregnant compared to non-pregnant cattle. In this study, variation exists between assay antibodies and animals. The antibody used in study 1 was more accurate in diagnosing pregnancy at a lower concentration compared to the assay antibody used in study 2 . In contrast to day 31 PAG concentrations, pregnant heifers had a lower PAG concentration compared to pregnant cows. The full extent of PAG concentrations being used to diagnose early gestation pregnant or non-pregnant cows has substantial potential and is early in the developmental process. Based on data in this study, there is merit to pursing this idea; however, identifying precise antibody combinations targeting specific PAGs will most likely provide the largest gains.

Following migration of binucleated trophoblast cells and interdigitation of microvilli on fetal and maternal membranes, PAGs enter the maternal circulation [28,29] and are detectable by a multitude of different assays. Pregnancy diagnosis through detection of PAGs is well established and available commercially in cattle and other ruminants beginning at day 28 of gestation [30]. Pregnancy associated glycoproteins may be detected in circulation of 


\section{Cows}

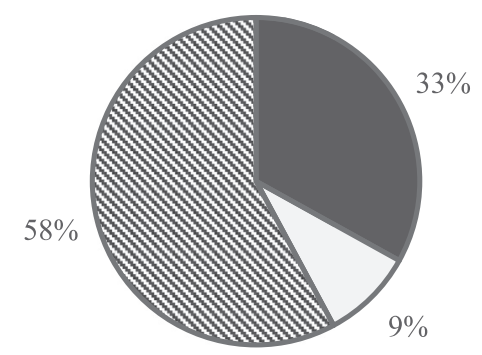

Pregnant aLikely EM Non Pregnant

\section{Heifers}

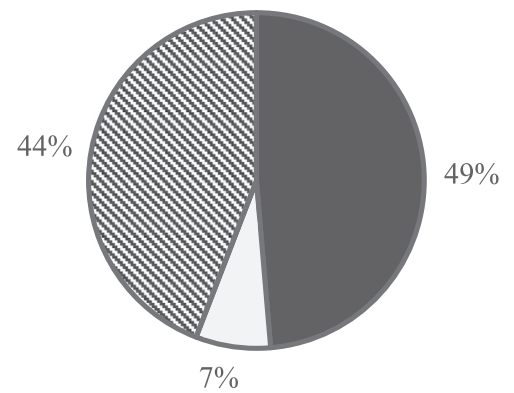

Pregnant aLikely EM $\mathbf{a}$ Non pregnant

Fig. 3. Study 2 pregnancy diagnosis results.

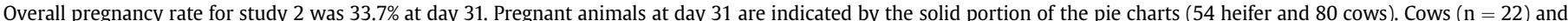

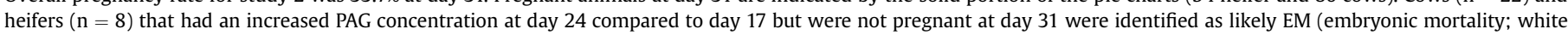
portion). Non pregnant animals (light shaded portion) made up a larger proportion of cows $(\mathrm{n}=140)$ than heifers $(\mathrm{n}=49)$.

some pregnant cows as early as day 21 of gestation by RIA in extremely small quantities, although pregnancy detection using serum PAG concentration earlier than day 28 has been variable in its accuracy [31-33]. Pohler et al. (2016) reported the first detectable and significant increase in circulating PAG concentration at day 24 of gestation in Nelore/cross bred beef cattle and Bos taurus beef cattle utilizing a similar polyclonal antibody used in the current study, thus the day of interest $[4,5]$. As expected, mean PAG concentrations were increased in pregnant animals compared to nonpregnant animals ( $2.32 \mathrm{ng} / \mathrm{mL}$ vs $0.7791 \mathrm{ng} / \mathrm{mL}$ ). Based on previous data, circulating PAG concentrations are influenced by a number of factors such as genetic background, sire, birth weight, parity of dam, and pregnancy stage $[5,34,35]$. Evidence also suggests that pregnancies resulting from IVP embryos may differ in circulating PAG concentration compared to AI or natural mating pregnancies and may be due to the irregularities that may accompany IVP embryo development $[8,36]$. Contradicting day 28-31 trends, PAG concentration at day 24 was decreased in pregnant heifers compared to pregnant cows in this study $[4,18]$. The depressed PAG concentrations at day 24 in heifers is not significantly different than cows and is based on a small sample size; however, more data are needed to confirm the presence or absence of a true biological difference. There are many reports that PAG concentrations differ between Bos taurus and Bos indicus breeds of cattle throughout gestation [35,37,38]. In a study by Mercadante et al. [38], cows with an increasing percentage of Bos indicus genetics ( $\geq 80 \%$ Brahman, $11.5 \mathrm{ng} / \mathrm{mL} ; 41-60 \%$ Brahman, $8.4 \mathrm{ng} / \mathrm{mL}$ ) had higher PAG concentration at day 35 of gestation compared to predominately Bos taurus cows ( $\geq 80$ Angus, $6.0 \mathrm{ng} / \mathrm{mL}$ ). In the current study at day 24 and 31 of gestation, however, there was no difference in PAG concentration based on breed ranging from $1 / 4$ to $7 / 8$ Holstein with the remaining genetic makeup being Bos indicus.

At day 24 of gestation, accurate pregnancy diagnosis using PAGs was variable between parities and assay, specifically the antibody

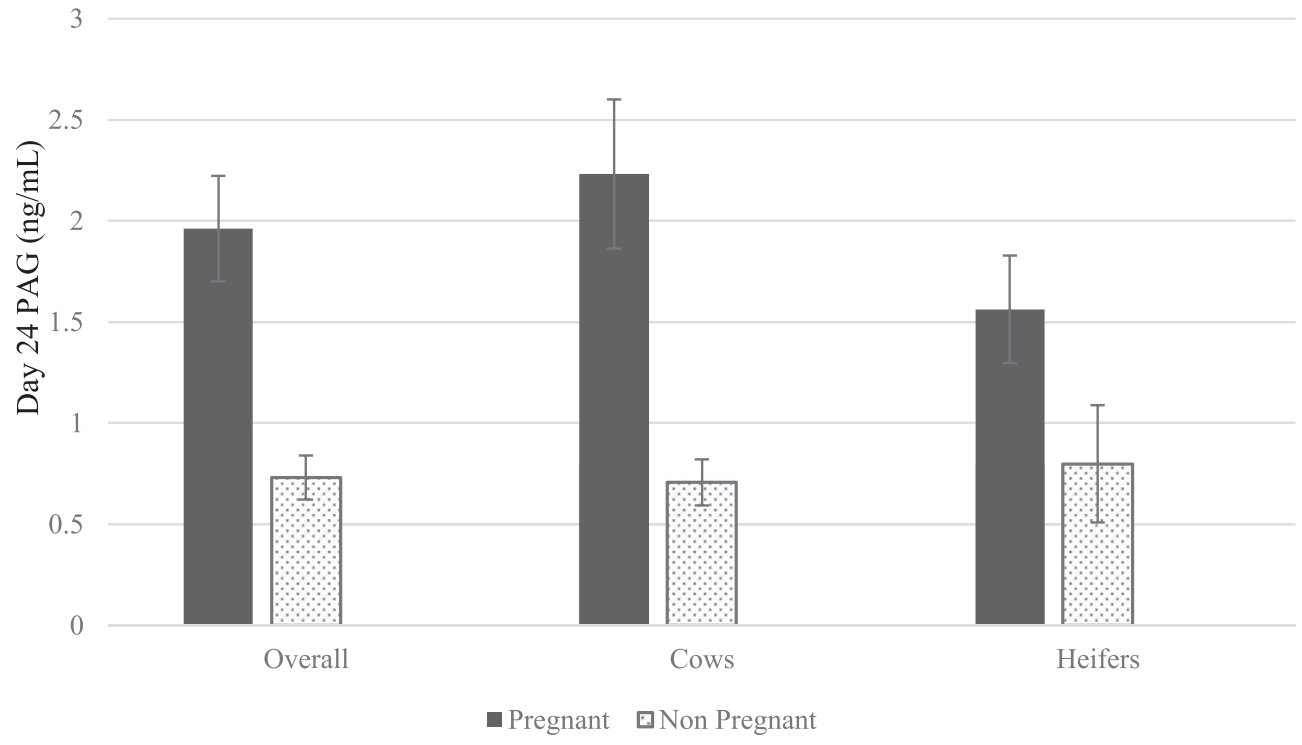

Fig. 4. Study 2 day 24 PAG concentration by parity.

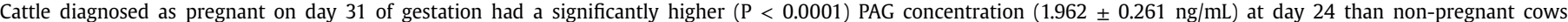

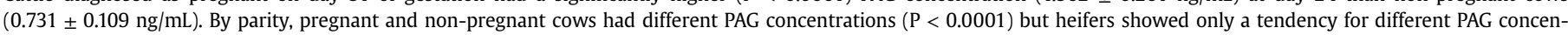
trations $(\mathrm{P}=0.0669)$. 


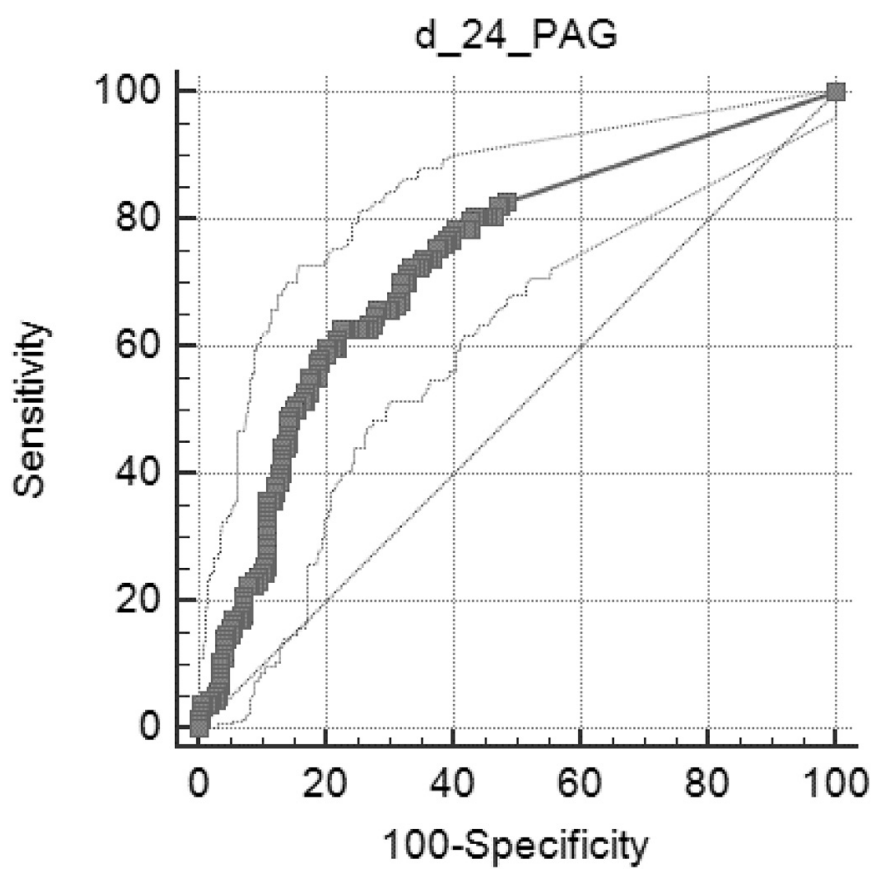

Fig. 5. Study 2 day 24 ROC curve using antibody 63 to diagnose pregnancy.

Receiver operating characteristic (ROC) curve was used to for predictive value analysis. The area under the curve was $73.4 \%$ and a positive predictive value at $90 \%$ confidence to diagnosis pregnancy at day 24 of $2.50 \mathrm{ng} / \mathrm{mL}$, a higher confidence level was not realistic as too few samples crossed the threshold.

used. Other studies have investigated the use of early gestation PAG testing with similar results. Ricci et al. [39] used a commercial based PAG ELISA with samples from day 25 of gestation and concluded that accuracy of the test was too low to be used effectively for pregnancy diagnosis. A study in Bos indicus beef cattle identified a significant increase in PAG concentrations in all pregnant cows at day 24 over earlier samples; however, in the same paper, another study was less conclusive in the ability of the assay to detect that increase [5]. One potential cause of this variation may be attributed to dissimilarity between PAGs secreted at or before day 24 of gestation and PAGs detected by the assay $[18,40]$. There is significant evidence that individual PAGs have distinct temporal secretion patterns with certain families and genes being expressed earlier or later in gestation but there is little information on the earliest secreted PAGs [40-42].

Based on ROC curve analysis from the data in study 2, only $32.1 \%$ of pregnant animals had a circulating PAG concentration greater than or equal to the positive predictive cut off value of $2.5 \mathrm{ng} / \mathrm{mL}$ at day 24 . Although only $74 \%$ of the animals with a $2.5 \mathrm{ng} / \mathrm{mL}$ concentration were pregnant on day 31 , only one animal did not have an increased day 31 PAG concentration compared to the day 24 sample indicating that embryo mortality may have occurred just prior to day 31 ultrasound diagnosis in many non-pregnant cows with elevated day 24 PAG concentrations. Additionally, 29.6\% of non-pregnant cows had a PAG concentration greater than $0.5 \mathrm{ng} /$ $\mathrm{mL}$ which may exceed concentrations expected when embryonic occurs loss between day 24-31 at the time of active placentation and exponential placentome development $[43,44]$. However, $38 \%$ of the non-pregnant cows with detectable circulating PAG $(0.5-1.0 \mathrm{ng} / \mathrm{mL})$ may have lost their pregnancy prior to day 24 as the antibody used in this assay has previously demonstrated to detect PAG up to 4 days after embryonic death at day 32 [4]. It is unlikely that animals with day 24 PAG concentrations over $1.0 \mathrm{ng} /$ $\mathrm{mL}$ would have lost pregnancy before day 24 due to limited PAG production that occurs early in gestation but this remains unknown. Assuming some pregnancy loss occurred prior to day 24, loss between day 24 and 31 may more closely complement the loss of $20.8 \%$ during the same period reported by Pohler et al. in lactating dairy cattle [8]. Time periods when the embryo and maternal environment undergo significant changes can be associated with increased loss including embryo elongation [45,46], maternal recognition of pregnancy $[10,47]$ and placentation $[8,48]$; however, an application for identification of non-pregnant cows needs to be both specific and sensitive. An increase in PAG concentration at day 24 compared to a baseline sample was not helpful in determining pregnancy status as only $71 \%$ of animals with a low

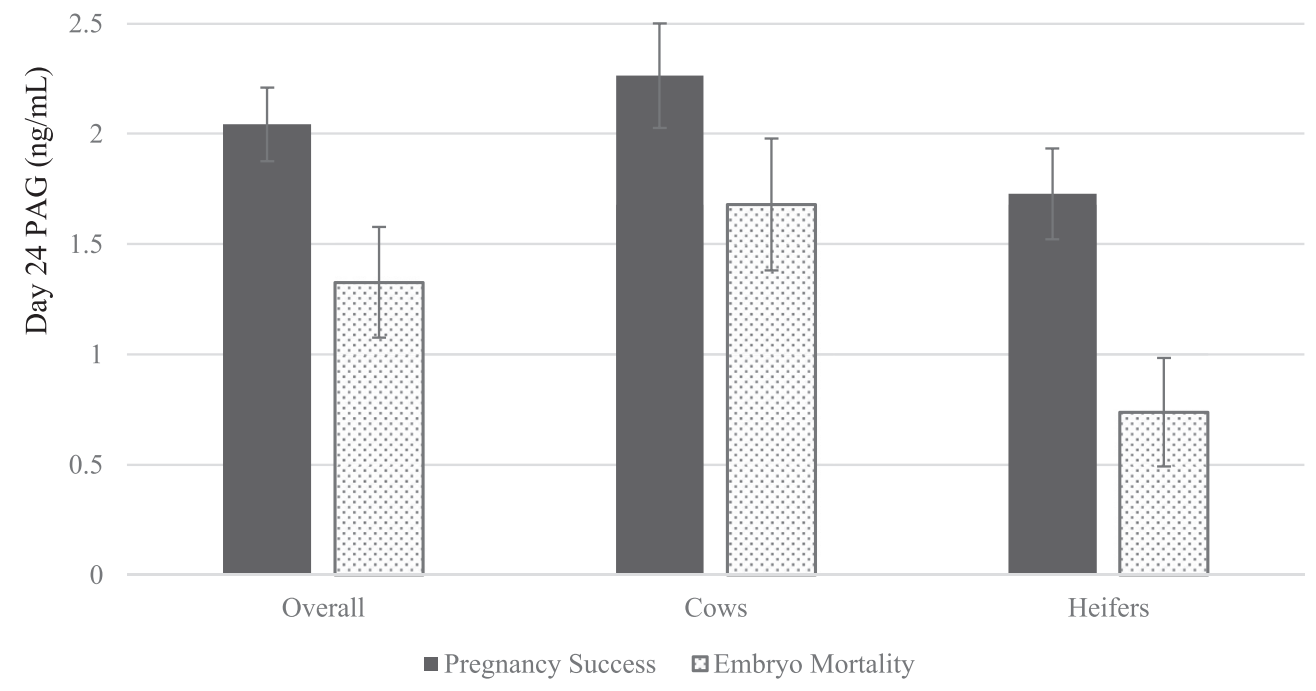

Fig. 6. Study 2 day 24 PAG concentration of pregnancy outcome by parity.

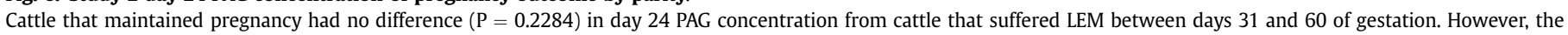
means of both cows and heifers that maintained pregnancy were increased over the LEM groups. 
baseline $(\leq 0.25 \mathrm{ng} / \mathrm{mL})$ and day 24 concentration of $\geq 0.75 \mathrm{ng} / \mathrm{mL}$ were pregnant on day 31 . Baseline day 17 samples could theoretically be useful for cows with an unknown calving date due to pregnancy specificity associated with PAG and known clearance rate. Assay refinement using antibodies targeted for the earliest secreted PAGs present on day 24 may provide more accurate results for pregnancy diagnosis.

Early gestation pregnancy diagnosis has important management and economic ramifications, especially with tests that may have the capacity to determine pregnancy success. Any potential pregnancy diagnosis method must be compared to the gold standard which is transrectal ultrasound. Limits of both must be considered. Pregnancy diagnosis based on day 31 PAG concentration has been shown to be comparable to accuracy from day 31 ultrasound $[30,39,49]$. Based on this set of data, the ability to detect nonpregnant animals by PAG concentration at day 24 is variable as evident by the inconclusive predictive cutoff value in both study 1 and 2 . The role of day 24 PAG concentration as an early non pregnant detection tool given the current assay platform seems unlikely due to high variability in both pregnant and non-pregnant samples at day 24 of gestation.

Incidences of late embryonic loss contribute a significant economic detriment to dairy producers by extending the days to last breeding, increasing feed costs and decreasing yearly milk production. In lactating dairy herds, LEM contributes an average $12 \%$ loss with farm to farm variation from $3.5 \%$ to over $25 \%[10,50]$. Significant evidence has been collected indicating increased day 28-32 PAG concentration has a strong correlation with greater embryo success in lactating dairy and beef cattle $[5,8,17]$. Commercial assays for pregnancy diagnosis are not accurate for predicting pregnancy maintenance in lactating dairy cows undergoing TAI; however, there has been some evidence for pregnancy maintenance prediction in lactating dairy cows undergoing TET $[8,39]$. Thus, predictive pregnancy outcome determination may require particular antibodies which present a greater sensitivity to specific PAGs and refinement for quantification of low concentrations. Day 31 samples collected from a subset of animals in this study contribute to this body of evidence. Animals that maintained pregnancy through day 60 of gestation had a PAG concentration at day 31 of $9.26 \mathrm{ng} / \mathrm{mL}$ whereas animals that lost pregnancy between day 31 and 60 had a PAG concentration of $7.04 \mathrm{ng} / \mathrm{mL}$. There was no difference in day 24 PAG concentration between animals that lost or maintained pregnancy between days 31-60 in either study. However, at day 24, heifers which experienced LEM (study 2) had a numerically decreased PAG concentration $(0.738 \mathrm{ng} / \mathrm{mL})$ compared to heifers which maintained pregnancy $(1.728 \mathrm{ng} / \mathrm{mL})$, although it was not significant, likely contributed to the low number of LEM pregnancies. With further assay refinement for day 24 PAGs, it may be possible to detect differences in the potential for embryo survival in cattle.

\section{Conclusion}

PAG concentrations at day 24 gestation are higher in pregnant compared to non-pregnant dairy cattle undergoing TET. The ability to diagnose pregnancy using specific concentrations based on predictive value analysis identified in study 1 and 2 did not detect all pregnant animals and no value was found to determine nonpregnant status with these specific antibody combinations. Embryo success could not be predicted in the current study based on day 24 PAG concentration; however, there was numerical differences between groups. Therefore, refining antibodies for assay specification aimed towards day 24 gestation PAGs may provide greater accuracy for pregnancy diagnosis and predictive success.

\section{Acknowledgements}

The authors would like to acknowledge Fazenda Santa Luzia dairy farm and its owner, Mauricio Silveira Coelho, for their role in the completion of this study.

\section{References}

[1] USDA. NAHMS Dairy. Part IV: reference of dairy cattle health and management practices in the United States. Fort Collins, CO: USDA: APHIS: VS C; 2007. p. 33-43. 2009.

[2] Youngquist R. Pregnancy diagnosis. In: Current therapy in large animal theriogenology. Philadelphia, PA: WB Saunders Co; 1997. p. 295-303.

[3] Fricke P. Scanning the future-ultrasonography as a reproductive management tool for dairy cattle. J Dairy Sci 2002;85:1918-26.

[4] Pohler KG, Geary TW, Johnson CL, Atkins JA, Jinks EM, Busch DC, et al. Circulating bovine pregnancy associated glycoproteins are associated with late embryonic/fetal survival but not ovulatory follicle size in suckled beef cows. J Anim Sci 2013;91:4158-67.

[5] Pohler K, Peres R, Green J, Graff H, Martins T, Vasconcelos J, et al. Use of bovine pregnancy-associated glycoproteins to predict late embryonic mortality in postpartum nelore beef cows. Theriogenology 2016;85:1652-9.

[6] Breukelman S, Perényi Z, Taverne M, Jonker H, Van der Weijden G, Vos P, et al. Characterisation of pregnancy losses after embryo transfer by measuring plasma progesterone and bovine pregnancy-associated glycoprotein-1 concentrations. Vet J 2012;194:71-6.

[7] Thompson I, Cerri R, Kim I, Green J, Santos J, Thatcher W. Effects of resynchronization programs on pregnancy per artificial insemination, progesterone, and pregnancy-associated glycoproteins in plasma of lactating dairy cows. J Dairy Sci 2010;93:4006-18.

[8] Pohler K, Pereira M, Lopes F, Lawrence J, Keisler D, Smith M, et al. Circulating concentrations of bovine pregnancy-associated glycoproteins and late embryonic mortality in lactating dairy herds. J Dairy Sci 2016;99:1584-94.

[9] Giordano J, Fricke P, Cabrera V. Economics of resynchronization strategies including chemical tests to identify nonpregnant cows. J Dairy Sci 2013;96: 949-61.

[10] Wiltbank MC, Baez GM, Garcia-Guerra A, Toledo MZ, Monteiro PL, Melo LF, et al. Pivotal periods for pregnancy loss during the first trimester of gestation in lactating dairy cows. Theriogenology 2016;86:239-53.

[11] Vasconcelos J, Silcox R, Lacerda J, Pursley J, Wiltbank M. Pregnancy rate, pregnancy loss, and response to head stress after ai at 2 different times from ovulation in dairy cows. Biol Reprod 1997:230-1.

[12] Cartmill J, El-Zarkouny S, Hensley B, Lamb G, Stevenson J. Stage of cycle incidence, and timing of ovulation, and pregnancy rates in dairy cattle after three timed breeding protocols. J Dairy Sci 2001;84:1051-9.

[13] Galvão K, Santos J, Juchem S, Cerri R, Coscioni A, Villaseñor M. Effect of addition of a progesterone intravaginal insert to a timed insemination protocol using estradiol cypionate on ovulation rate, pregnancy rate, and late embryonic loss in lactating dairy cows. J Anim Sci 2004;82:3508-17.

[14] Taverne MA, Breukelman SP, Perényi Z, Dieleman SJ, Vos PL, Jonker HH, et al. The monitoring of bovine pregnancies derived from transfer of in vitro produced embryos. Reprod Nutr Dev 2002;42:613-24.

[15] Farin PW, Piedrahita JA, Farin CE. Errors in development of fetuses and placentas from in vitro-produced bovine embryos. Theriogenology 2006;65: $178-91$.

[16] Scully S, Evans A, Carter F, Duffy P, Lonergan P, Crowe M. Ultrasound monitoring of blood flow and echotexture of the corpus luteum and uterus during early pregnancy of beef heifers. Theriogenology 2015;83:449-58.

[17] Pohler K, Geary T, Johnson C, Atkins J, Jinks E, Busch D, et al. Circulating bovine pregnancy associated glycoproteins are associated with late embryonic/fetal survival but not ovulatory follicle size in suckled beef cows. J Anim Sci 2013;91:4158-67.

[18] Green JA, Parks TE, Avalle MP, Telugu BP, McLain AL, Peterson AJ, et al. The establishment of an elisa for the detection of pregnancy-associated glycoproteins (pags) in the serum of pregnant cows and heifers. Theriogenology 2005;63:1481-503.

[19] Harlow E, Lane D. Antibodies: a laboratory manual New York Cold. Springs Harbor Labratory; 1988. p. 107-98.

[20] Herzog K, Brockhan-Ludemann M, Kaske M, Beindorff N, Paul V, Niemann H, et al. Luteal blood flow is a more appropriate indicator for luteal function during the bovine estrous cycle than luteal size. Theriogenology 2010;73: 691-7.

[21] Diskin M, Parr M, Morris D. Embryo death in cattle: an update. Reprod Fertil Dev 2011;24:244-51.

[22] Diskin MG, Murphy JJ, Sreenan JM. Embryo survival in dairy cows managed under pastoral conditions. Anim Reprod Sci 2006;96:297-311.

[23] Pereira M, Wiltbank M, Vasconcelos J. Expression of estrus improves fertility and decreases pregnancy losses in lactating dairy cows that receive artificial insemination or embryo transfer. J Dairy Sci 2016;99:2237-47.

[24] Mikkola M, Andersson M, Taponen J. Transfer of cattle embryos produced with sex-sorted semen results in impaired pregnancy rate and increased male calf mortality. Theriogenology 2015;84:1118-22. 
[25] De Rensis F, Garcia-Ispierto I, López-Gatius F. Seasonal heat stress: clinical implications and hormone treatments for the fertility of dairy cows. Theriogenology 2015;84:659-66.

[26] De Rensis F, Lopez-Gatius F, García-Ispierto I, Morini G, Scaramuzzi R. Causes of declining fertility in dairy cows during the warm season. Theriogenology 2016;91:145-53.

[27] Pontes J, Silva K, Basso A, Rigo A, Ferreira C, Santos G, et al. Large-scale in vitro embryo production and pregnancy rates from bos taurus, bos indicus, and indicus-taurus dairy cows using sexed sperm. Theriogenology 2010;74: $1349-55$.

[28] Wooding F, Wathes DC. Binucleate cell migration in the bovine placentome. J Reprod Fertil 1980;59:425-30.

[29] Wooding P, Burton G. Synepitheliochorial placentation: ruminants (ewe and cow). In: Comparative placentation: structures, functions and evolution. Berlin: Springer; 2008. p. 133-67.

[30] Reese S, Pereira M, Vasconcelos J, Smith M, Green J, Geary T, et al. Markers of pregnancy: how early can we detect pregnancies in cattle using pregnancyassociated glycoproteins (pags) and micrornas? Anim Reprod 2016;13:200-8.

[31] Silva E, Sterry R, Kolb D, Mathialagan N, McGrath M, Ballam J, et al. Accuracy of a pregnancy-associated glycoprotein elisa to determine pregnancy status of lactating dairy cows twenty-seven days after timed artificial insemination. J Dairy Sci 2007;90:4612-22.

[32] Sousa N, Ayad A, Beckers J, Gajewski Z. Pregnancy-associated glycoproteins (pag) as pregnancy markers in the ruminants. J Physiol Pharmacol 2006;57: $153-71$.

[33] Perényi Z, Szenci O, Sulon J, Drion P, Beckers J-F. Comparison of the ability of three radioimmunoassay to detect pregnancy-associated glycoproteins in bovine plasma. Reprod Domest Anim 2002;37:100-4.

[34] Patel OV, Sulon J, Beckers JF, Takahashi T, Hirako M, Sasaki N, et al. Plasma bovine pregnancy-associated glycoprotein concentrations throughout gestation in relationship to fetal number in the cow. Eur J Endocrinol 1997;137: 423-8.

[35] Lobago F, Bekana M, Gustafsson H, Beckers J-F, Yohannes G, Aster Y, et al. Serum profiles of pregnancy-associated glycoprotein, oestrone sulphate and progesterone during gestation and some factors influencing the profiles in ethiopian borana and crossbred cattle. Reprod Domest Anim 2009;44: 685-92.

[36] Constant F, Camous S, Chavatte-Palmer P, Heyman Y, De Sousa N, Richard C, et al. Altered secretion of pregnancy-associated glycoproteins during gestation in bovine somatic clones. Theriogenology 2011;76:1006-21.

[37] de Sousa NM, Zongo M, Pitala W, Boly H, Sawadogo L, Sanon M, et al. Pregnancy-associated glycoprotein concentrations during pregnancy and the postpartum period in azawak zebu cattle. Theriogenology 2003;59:1131-42.

[38] Mercadante P, Waters K, Mercadante V, Lamb G, Elzo M, Johnson S, et al. Subspecies differences in early fetal development and plasma pregnancyassociated glycoprotein concentrations in cattle. J Anim Sci 2013;91: 3693-701.

[39] Ricci A, Carvalho P, Amundson M, Fourdraine R, Vincenti L, Fricke P. Factors associated with pregnancy-associated glycoprotein (pag) levels in plasma and milk of holstein cows during early pregnancy and their effect on the accuracy of pregnancy diagnosis. J Dairy Sci 2015;98:2502-14.

[40] Green JA, Xie S, Quan X, Bao B, Gan X, Mathialagan N, et al. Pregnancy-associated bovine and ovine glycoproteins exhibit spatially and temporally distinct expression patterns during pregnancy. Biol Reprod 2000;62:1624-31.

[41] Telugu BPV, Walker AM, Green JA. Characterization of the bovine pregnancyassociated glycoprotein gene family-analysis of gene sequences, regulatory regions within the promoter and expression of selected genes. BMC Genomics 2009; 10:185.

[42] Touzard E, Reinaud P, Dubois O, Guyader-Joly C, Humblot P, Ponsart C, et al. Specific expression patterns and cell distribution of ancient and modern pag in bovine placenta during pregnancy. Reproduction 2013;146:347-62.

[43] Leiser R. Development of contact between trophoblast and uterine epithelium during the early stages on implantation in the cow. Zentralbl Veterinarmed $1975 ; 4: 63-86$.

[44] King G, Atkinson B, Robertson H. Development of the bovine placentome during the second month of gestation. J Reprod Fertil 1979;55. 173-NP.

[45] Brooks K, Burns G, Spencer TE. Conceptus elongation in ruminants: roles of progesterone, prostaglandin, interferon tau and cortisol. J Anim Sci Biotechnol 2014;5:53.

[46] Spencer TE, Sandra O, Wolf E. Genes involved in conceptus-endometrial interactions in ruminants: insights from reductionism and thoughts on holistic approaches. Reproduction 2008;135:165-79.

[47] Thatcher W, Guzeloglu A, Mattos R, Binelli M, Hansen T, Pru J. Uterineconceptus interactions and reproductive failure in cattle. Theriogenology 2001;56:1435-50.

[48] Barański W Zduńczyk S, Janowski T. Late embryonic and foetal losses in eight dairy herds in north-east Poland. Pol J Vet Sci 2012;15:735-9.

[49] Karen A, De Sousa NM, Beckers JF, Bajcsy AC, Tibold J, Madl I, et al. Comparison of a commercial bovine pregnancy-associated glycoprotein elisa test and a pregnancy-associated glycoprotein radioimmunoassay test for early pregnancy diagnosis in dairy cattle. Anim Reprod Sci 2015;159:31-7.

[50] Santos J, Thatcher W, Chebel R, Cerri R, Galvao K. The effect of embryonic death rates in cattle on the efficacy of estrus synchronization programs. Anim Reprod Sci 2004;82:513-35. 